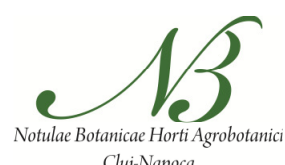

Cluj-Napoca

Original Article

\title{
Field Pea in European Cropping Systems: Adaptability, Biological Nitrogen Fixation and Cultivation Practices
}

\author{
Anestis KARKANIS ${ }^{1}$, Georgia NTATSI², \\ Charis-Konstantina KONTOPOULOU ${ }^{2}$, Aurelio PRISTERI ${ }^{3}$, \\ Dimitrios BILALIS ${ }^{2}$, Dimitrios SAVVAS ${ }^{2 *}$
${ }^{1}$ University of Thessaly, Department of Agriculture Crop Production and Rural Environment, Fytokou Str, 38446, N. Ionia, Magnisia, Greece; akarkanis@agr.uth.gr
${ }^{2}$ Agricultural University of Athens, Faculty of Plant Science, Iera Odos 75, 11855 Athens, Greece; ntatsi@aua.gr; xariskon@gmail.com; bilalis@aua.gr;dsavvas@aua.gr(*0orrespondingauthor)
${ }^{3}$ Università Mediterranea di Reggio Calabria I-89122 Reggio Calabria, Italy; aurelio.pristeri@unirc.it

\begin{abstract}
This article provides an overview of the production and use of field pea in European farming systems. Pea is cultivated in Europe for both human consumption and for animal feeding. For food, pea is consumed as dry seeds, green pods or green seeds (fresh, canned or frozen). Field pea is also used for animal feed. Pea production has declined in the region; however, interest in pea cultivation has recently revived. Pea production provides several agronomic advantages in the Mediterranean region supporting more sustainable cropping systems and reduced nitrogen fertiliser use. Furthermore, peas for animal feed partly substitute for the increasingly expensive imported soybean. In addition to describing the current situation of pea cultivation and the future perspectives, this article reports on the adaptability of pea in Europe, cropping techniques with emphasis on modern farming practices and varieties that make their cultivation more profitable and more attractive to growers, and the cropping systems that are commonly used for field pea production. The currently applied cropping practices in the region, including rotation, soil tillage practices, fertilisation, sowing and crop density, weed, pest and disease management, irrigation and harvesting, are outlined.
\end{abstract}

Keywords: acclimation, diseases, biological nitrogen fixation (BNF), pests, Pisum sativum, weed management

\section{Introduction}

Pulses are high protein foods that are used for human and animal nutrition around the world. The human consumption of pulses is lower in Europe than in other regions of the world (Schneider, 2002). In Europe, however, field pea is an important pulse crop used for both livestock feed and human nutrition. Field pea, which is also known as common pea, dry pea, yellow pea and garden pea, is a cool-season legume cultivated worldwide. 'Green pea' is the term used by the FAO for peas harvested when the seed is still green and succulent to be eaten as a vegetable either fresh or processed.

World grain pea production in 2013 was 11 million tons (Table 1). About 5.5 million tonnes less than in 1990 when the highest worldwide production was registered (FAOSTAT,
2015). This reduction was largely due to the loss of 4 million hectares in Europe, only in part compensated by an increase in cultivated areas and productions in America.

Soil organic matter is generally low in southern Europe. Inclusion of pulses legumes in cropping sequences improves soil fertility and properties particularly soil organic nitrogen (Carranca et al., 1999), organic matter, and soil biological activities (Piotrowska and Wilczewski, 2012). Faba bean and vetch generally produce more biomass and accumulate more $\mathrm{N}$ than pea (Carranca et al., 1999; Bilalis et al., 2012). Field peas have the capacity to increase the availability of phosphorus for the following crop (Ha et al., 2007) and they are used also in intercropping systems to improve $\mathrm{N}$ use efficiency, as has been shown with field pea-wheat intercropping (Ghaley et al., 2005). Maximising $\mathrm{N}_{2}$ fixation while minimising soil $\mathrm{N}$ losses through denitrification and nitrate leaching is a challenging target (Corre-Hellou and Crozat, 2005; Poudel et al., 2001). 
326

Table 1. Production (in tonnes) and area harvested (in hectare) of dry peas in the world in 1972, 1990 and 2013 (FAOSTAT, 2015)

\begin{tabular}{lcccccc}
\hline \multirow{2}{*}{ World regions } & \multicolumn{2}{c}{1972} & \multicolumn{2}{c}{1990} & \multicolumn{2}{c}{2013} \\
\cline { 2 - 7 } & Production & Area harvested & Production & Area harvested & Production & Area harvested \\
\hline Africa & 317,368 & 434,633 & 266,621 & 402,807 & 719,546 & 811,815 \\
Asia & $2,839,814$ & $3,104,299$ & $2,276,785$ & $1,822,853$ & $2,229,016$ & $1,875,177$ \\
Americas & 265,758 & 229,683 & 525,863 & 350,838 & $4,748,067$ & $1,787,712$ \\
Europe & $5,068,165$ & $4,286,156$ & $13,192,740$ & $5,791,026$ & $3,020,567$ & $1,723,501$ \\
Oceania & 72,833 & 45,099 & 375,447 & 335,787 & 262,750 & 181,330 \\
World total & $8,536,938$ & $8,099,870$ & $16,637,456$ & $8,703,311$ & $10,979,946$ & $6,379,535$ \\
\hline
\end{tabular}

\section{History, origin and distribution}

Pisum is a small genus in the Fabaceae family (Fig. 1). The genetic diversity level in the wild species $P$. fulvum is much lower than the cultivated species $P$. sativum (Zong et al., 2009). The word 'pea' has its origin to the Italian word: pisello (derived by the Latin: pisselo) which has can be traced to the ancient Greek word 'pison' ('ii in Abyssinia and Afghanistan, with areas in the Mediterranean area colonised later. Then, pea spread to other regions of Europe and Asia (Cousin, 1997). Pea was probably domesticated in the Middle East, simultaneously with wheat and barley, not later than the sixth millennium B.C (Zohary and Hopf, 1973).

\section{Uses}

Pea is one of the most popular pulse crops and has various uses for human consumption. Snow peas and podded sugar peas are eaten as whole pods ('mangetout'). Immature pea seeds (green peas or 'vining' peas) are also usually canned or frozen and used as the familiar vegetable. Dry peas, for example marrowfat peas, are widely used for soups and similar dishes.

Pea seeds are nutritious due to their high protein content (23 to $31 \%$ of seed dry matter), minerals, carbohydrates and fibre (Dahl et al., 2012; Gueguen and Barbot, 1988; Świątecka et al., 2010). Moreover, peas contain several active compounds. These include polyphenolics, vitamins, saponins and galactose oligosaccharides (Dahl et al., 2012). Seed composition is influenced by climate and soil (Nikolopoulou et al., 2007).

For livestock feed, Lanza et al. (2003) noted that replacing soybean meal with peas did not significantly affect the growth and meat quality of lambs. According to Brenes et al. (1989) and Gatel and Grosjean (1990) pea seeds are used for nonruminants animals (i.e. pigs, poultry) feeding in Europe. Field

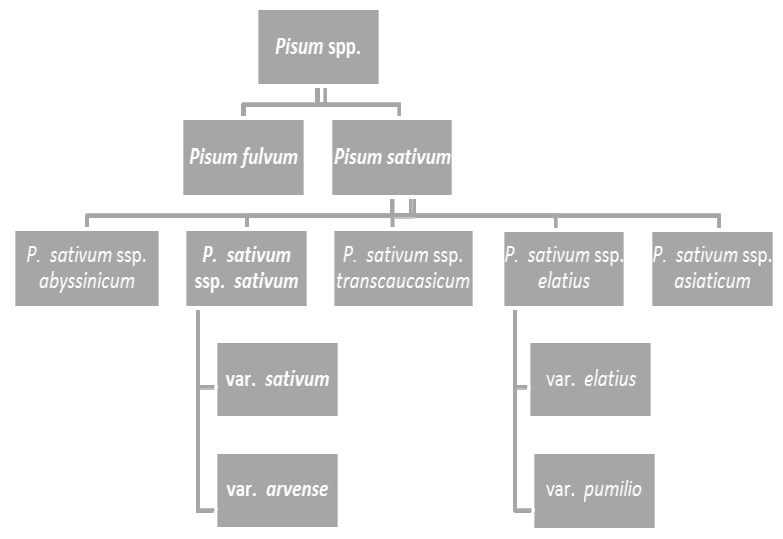

Fig. 1. Taxonomy of Pisum genus ( Zong et al., 2009) peas are also grown as forage crop for hay. Intercropping field peas with cereals for forage has become more common in recent years. Lithourgidis et al. (2011) observed that peatriticale and pea-wheat mixtures produced better forage quality (high crude protein yield) than the other mixtures.

\section{Pea adaptability-Abiotic stress acclimation}

Pea is well adapted to a wide range of climates from semiarid to temperate maritime. In central and northern Europe peas is generally sown in spring whereas in southern Europe they are mostly sown in mid-November (Fig. 2.). In Northern Europe, autumn sowing should be avoided due to greater risk of frost damage during flowering. The optimum and base germination temperatures are around $20{ }^{\circ} \mathrm{C}$ and $1.1{ }^{\circ} \mathrm{C}$, respectively (Raveneau et al., 2011). However, the risk of frost damage depends on the stage of plant development. According to Meyer and Badaruddin (2001) $-4.5^{\circ} \mathrm{C}$ kills 50\% of seedlings. In general, pulses are sensitive to freezing temperatures, particularly at the flowering, early pod formation and seed filling stages (Maqbool et al., 2010).

Pea tolerates frost if it is already exposed to low temperatures, a process known as cold acclimation (Bourion et al., 2003). Cysteine and methionine production has been correlated with pea tolerance to low temperatures (Legrand $e t$ al., 2013). In Italy, Annicchiarico and Filippi (2007) observed that autumn sowing led to higher yields (+56\%) than spring

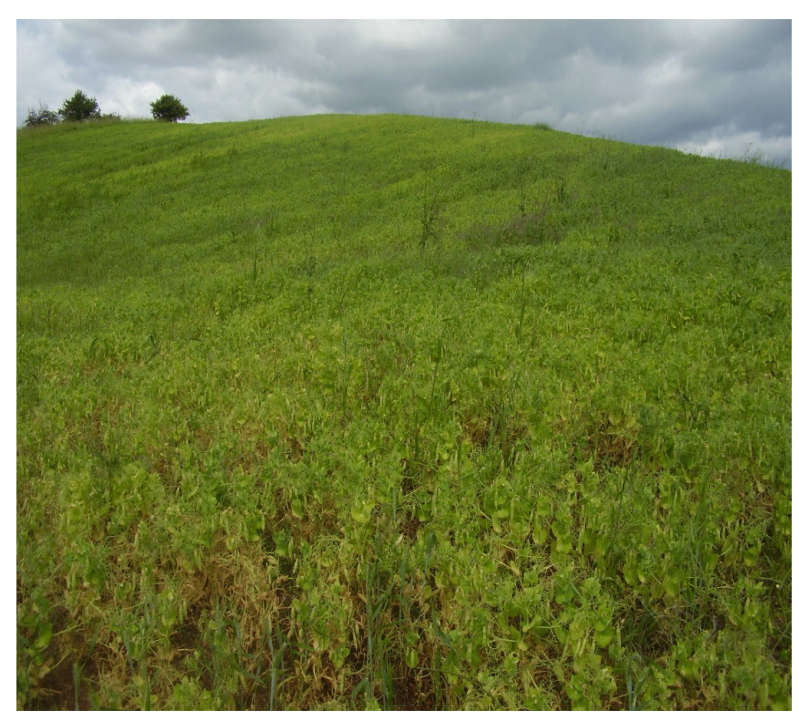

Fig. 2. Established winter field pea crop 5 months after sowing (April 2012) in central Greece (Agios Georgios-Domokos) 
sowing. Soil compaction and high temperatures or water stress during flowering and grain filling affects the growth and yield of pea crop. Moreover, winter peas flower earlier, and thus should be less vulnerable to drought stress at the end of the cycle (Vocanson and Jeuffroy, 2008).

In semi-arid regions, crop management practices, such as early sowing are important for avoiding drought stress (Khan $e t$ al., 2010). Because of the high sensitivity to waterlogging, pea should not be cultivated on soils with low infiltration rates, while pea is very sensitive to salinity (Duzdemir et al., 2009). Recently, some interesting landraces originating from China and Greece were identified as more salt tolerant and could be used in breeding programmes to improve the salinity tolerance in field pea crops (Leonforte et al., 2013).

\section{Agronomy}

\section{Varieties}

There is much genetic variation in cultivated pea and a wide range of varieties with a wide range of traits are available. When selecting a pea variety, crop use, region, sowing date, yield potential, frost and diseases resistance or tolerance, harvesting ease and marketing options are considered. The pea varieties 'Kabuki', 'Oasis', 'Onward', 'Progress N.9', 'Rondo', 'Utrillo', 'Tukano', 'Zero 4', 'Assas', 'Dove, 'Isard', 'Canion', 'Carumbi' are widely cultivated in southern Europe. Further information about pea varieties should be obtained from the seed trade.

The major risk (apart from drought) in autumn-sown pea is frost and ascochyta blight (Le May et al., 2009; Shafiq et al., 2012) while, according to Rubiales et al. (2009a) in Mediterranean region, the autumn sown peas are infected by crenate broomrape (Orobanche crenata Forsk.) and foliar diseases (i.e. rusts (Uromyces pisi (Pers.) Wint.), powdery mildew (Erysiphe pisi Boerema \& Verh). Thus, effort should be made to develop varieties resistant or tolerant to frost, broomrape and diseases.

In France, Le May et al. (2009) reported that a new type of winter pea ( $\mathrm{Hr}$ genotype) exhibited the lowest level of disease incidence. Increasing grain legume yield by extending the growing season using autumn sowing requires winter-hardy material (Annicchiarico and Iannuci, 2007). Shafiq et al. (2012) reported that five field pea accessions (ATC 104, ATC 377, ATC 968, ATC 3992 (and ATC 4204) showed the highest frost tolerance during the flowering stage. Therefore, frost and disease tolerant genotypes are available for improving the pea crop.

\section{Crop establishment and crop rotation}

The seedbed for pea must be well prepared, usually following ploughing. However, pea has been characterized as very sensitive to soil compaction that significantly reduces pea growth and nitrogen fixation (Siczek et al., 2013). In another study, Hebblethwaite and McGowan (1980) illustrated a 50\% yield reduction in vined peas due to top soil compaction, whereas Vocanson et al. (2006a) demonstrated this sensitivity in spring-sown peas that are sown early. Reduced or conservation tillage is used in semiarid regions in particular. Carr et al. (2009) reported that pea seed yield was increased by $13 \%$ when grown under zero tillage compared with conventional tillage. Under other conditions, Deibert and Utter (2004) observed that field pea will grow equally well regardless of tillage system. Optimum germination occurs at $15-20{ }^{\circ} \mathrm{C}$ and the recommended sowing depth is $2-5 \mathrm{~cm}$. Field peas can tolerate deep seeding, down to $7.5 \mathrm{~cm}$ (Johnston and Stevenson, 2001) but deeper sowing depth may lead to increased variability in emergence time (Ayaz et al., 2004). Row spacing is usually $20-50 \mathrm{~cm}$, with $10-20 \mathrm{~cm}$ between plants in the row (Elkoca and Kantar, 2006). As cited by Gan et al. (2003), the highest seed yield was obtained at 75-80 plants $\mathrm{m}^{-2}$. Other experiments have identified higher optimum seeding rates. In Canada, Spies et al. (2010) reported that the optimum plant density in field pea is 88 plants $\mathrm{m}^{-2}$.

The inclusion of grain legumes in cropping systems leads to an increase in yield of following crops. These cropping systems have also reduced input requirements (MacWilliam et al., 2014). Pea yields are reduced if grown frequently due to root disease, other effects on the root system with reduced biological nitrogen fixation with adverse effects on nutrient cycling (Lupwayi et al., 2012; Knight, 2012). Crop rotation is an effective cultural method to control pea diseases. Ascochyta blight (Mycosphaerella pinodes) is a serious disease. An interval of at least 6 years is required to reduce the amount of ascochyta blight propagules by $90 \%$ (McDonald and Peck, 2009).

\section{Fertilisation-nitrogen fixation}

Fertiliser nitrogen is not generally required. Usually, applying nitrogen reduces nitrogen fixation but starter nitrogen applied early prior to the onset of nitrogen fixation has been recommended for field pea production when soils are low in nitrogen (Clayton et al., 1998). McKenzie et al. (2001) reported that are rarely no benefits from using starter $\mathrm{N}$ and where there are, these are generally small. In another study, Deibert and Utter (2004) reported that the highest seed yields (3.5 $\mathrm{t} \mathrm{ha}^{-1}$ ) were obtained when $135 \mathrm{~kg} \mathrm{ha}^{-1}$ nitrogen fertiliser was applied. Brkic et al. (2004) also observed that foliar molybdenum application increased total dry weight of nodules per plant. Nodules accumulate molybdenum which is required in order to support bacterial nitrogenase activity and symbiotic nitrogen fixation (Kaiser et al., 2005).

Phosphorus is required for pea growth and nitrogen fixation. Sandaña and Pinochet (2014) reported that phosphorus uptake of pea ranged from 1.55 to $2.98 \mathrm{~kg} \mathrm{ha}^{-1}$. Therefore, the application of $30-35 \mathrm{~kg} \mathrm{ha}^{-1} \mathrm{P}_{2} \mathrm{O}_{5}$ is sufficient to meet the crop requirement (Lafond and Pageau, 2010). Others researchers reported that pea responds to high fertilization rates. Tawaha and Turk (2004) found that field pea yields were maximised by high seeding rate $\left(90\right.$ seeds $\mathrm{m}^{-2}$ ) and high $\mathrm{P}$ fertilisation levels $\left(53 \mathrm{~kg} \mathrm{ha}^{-1}\right)$. Phosphorus fertilisation should be based on soil analysis. The higher rates of phosphorus fertilization are recommended if phosphorus is deficient in the soil. On soils with optimum to high P levels, farmers should add the amount of phosphorus removed by pea crop and thus maintain the soil with an adequate phosphorus level. Phosphorus deficiency cause purple colour in leaves. Moreover, in soils with moderate plant available $\mathrm{K}$ status, the application of $50 \mathrm{~kg} \mathrm{ha}^{-1}$ is sufficient to meet the crop requirements and maintain the soil fertility (Lafond and Pageau, 2010).

Sulphur deficiencies have been recently also observed to the Mediterranean areas due to low application of sulphur fertilizers, as well as reduced atmospheric deposition of sulphur 


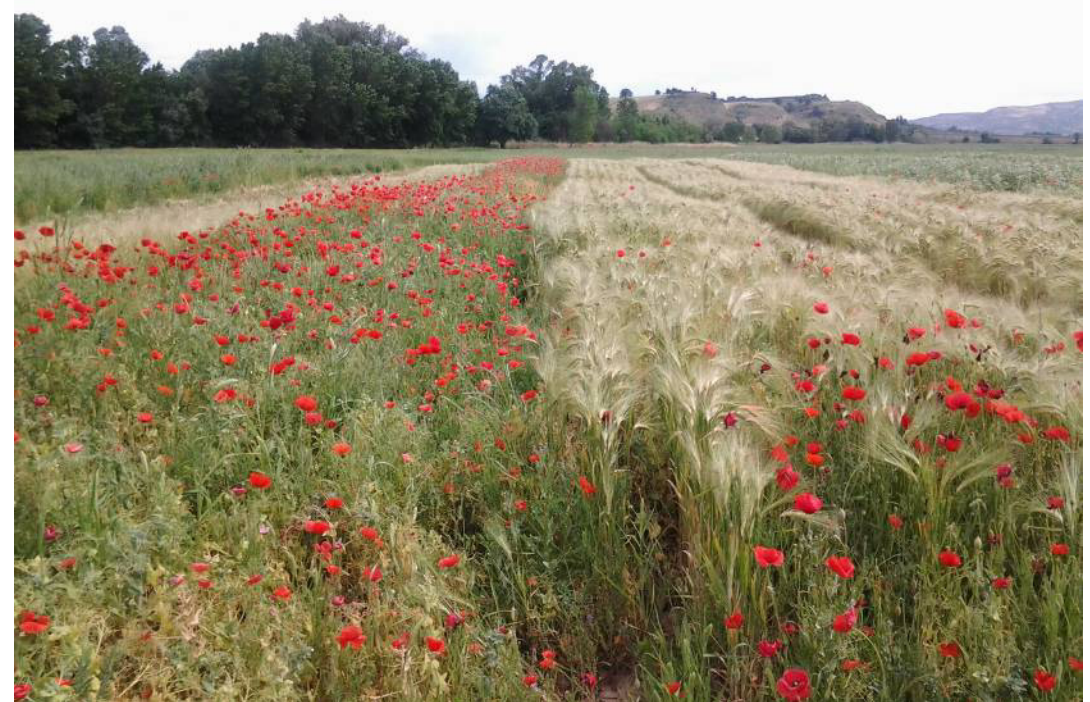

Fig. 3. Weed suppression in pea-barley intercropping system (right) compared with barley sole crop (left) in South Italy (San Marco Argentano)

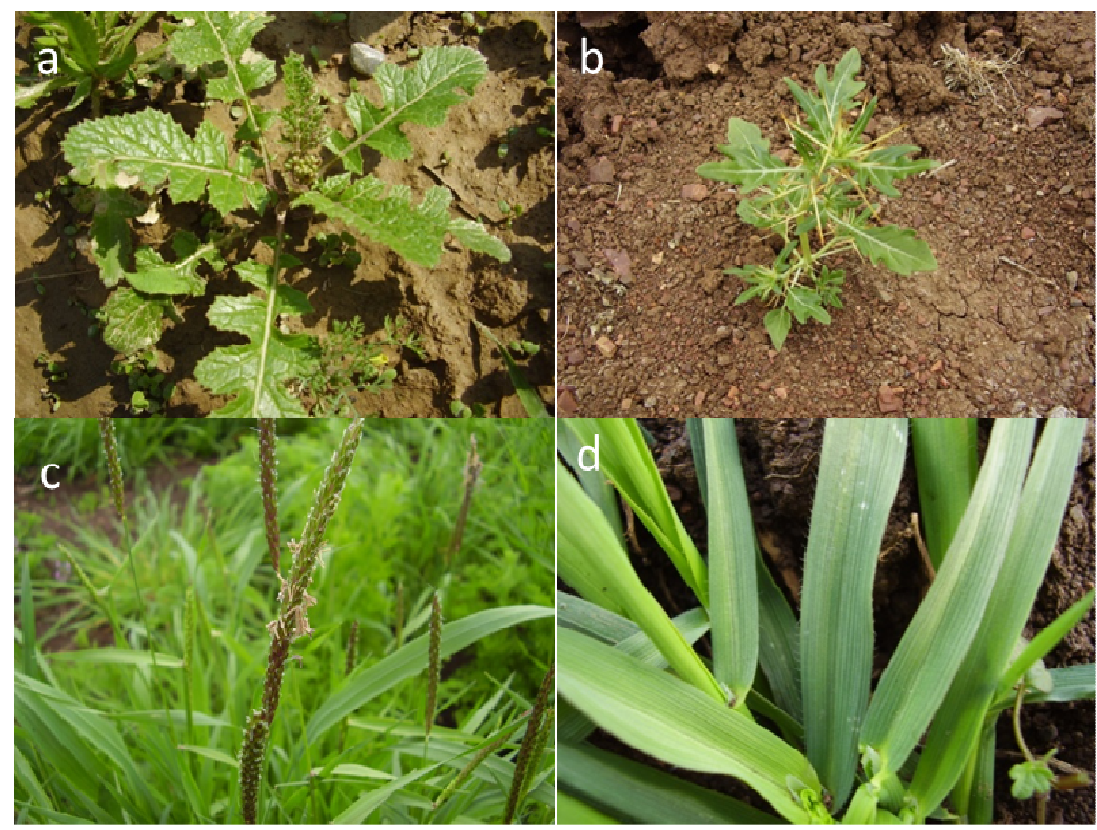

Fig. 4. Important weeds in pea crops in Europe: a) wild mustard, b) spiny cocklebur, c) blackgrass and d) wild oat

(Gallejones et al., 2012). Sulphur deficiency resulted in decreased nitrogen fixation (Pacyna et al., 2006), while other researchers (Scherer and Lange, 1996) marked the importance of sulphur in legumes due to their high protein concentration. Specifically, the role of sulphur in pea cultivation is closely connected with symbiotic nitrogen fixation and nitrogen nutrition. In a pot experiment with pea, Zhao et al. (1999) pointed out that addition of sulphur increased significantly the seed yield, the total amount of nitrogen in the shoots and double the nitrogen fixation. Cazzato et al. (2014) suggested sulphur fertilization in winter legume grains (including pea) in Mediterranean areas to increase their fatty acid profile.

\section{Weed control}

Weed infestation lowers crop yields by competing for soil moisture, nutritive substances, space and light, harbouring various insects and fungi and making harvest difficult. Fernandez et al. (2012) observed that weed control increased pea yields by an average of $63 \%$, while in another study Harker et al. (2001) reported that pea yield losses due to weed competition ranged from 40 to $70 \%$.

With current pressures to reduce herbicide application while maintaining current level of weed control, the ability of varieties to suppress weed growth has become important (Efthimiadou et al., 2009). Traits such as branching, long 
Table 2. The 25 most common weeds in field pea crops in Europe

\begin{tabular}{lll}
\hline Scientific name & Family & $\begin{array}{l}\text { Life cycle-weed } \\
\text { type }\end{array}$ \\
\hline Anthemis arvenis & Asteraceae & A-BL \\
\hline Chamomilla recutita & Asteraceae & A-BL \\
\hline Cirsium arvense & Asteraceae & P-BL \\
\hline Lactuca serriola & Asteraceae & A or B-BL \\
\hline Sonchus spp & Asteraceae & A-BL \\
\hline Xanthium spinosum & Asteraceae & A-BL \\
\hline Lithospermum arvense & Boraginaceae & A-BL \\
\hline Capsella bursa-pastoris & Brassicaceae & A-BL \\
\hline Sinapis arvensis & Brassicaceae & A-BL \\
\hline Stellaria media & Caryophyllaceae & A-BL \\
Chenopodium album & Chenopodiaceae & A-BL \\
\hline Viccia cracca & Fabaceae & A-BL \\
\hline Fumaria officinalis & Fumariaceae & A-BL \\
\hline Lamium amplexicaule & Lamiaceae & A-BL \\
\hline Hibiscustrionum & Malvaceae & A-BL \\
\hline Orobanche crenata & Orobanchaceae & A-Pa \\
\hline Papaver rhoeas & Papaveraceae & A-BL \\
\hline Alopecurus myosuroides & Poaceae & A-G \\
\hline Avena sterilis & Poaceae & A-G \\
\hline Bromus spp. & Poaceae & A-G \\
\hline Lolium spp. & Poaceae & A-G \\
\hline Phalaris spp. & Poaceae & A-G \\
\hline Polygonum aviculare & Polygonaceae & A-BL \\
\hline Galium aparine & Rubiaceae & A-BL \\
\hline Veronica spp. & Scrophulariaceae & A-BL \\
\hline A=annual, P=perennial, B=biennial, BL=broadleaved, G=grass, Pa=Parasitic \\
\hline
\end{tabular}
weed

stems, leaf area and rapid canopy development affect pea/weed interactions. The forage pea cultivars, which were leafed and had longer vines, are more competitive than the semi-leafless grain cultivars (Spies et al., 2011). Both leafed and semi-leafless varieties are widely cultivated in Southern Europe. Harker $e t$ al. (2008) reported that leafy pea grown in Canada had a lower yield potential under less weedy conditions than the semileafless pea, but the former pea types were less susceptible to yield reduction as weed competition increased.

Integrated weed management combining all the available methods is the key to successful control of weeds (Fig. 3). Pristeri et al. (2012) observed that pea suppresses weeds more than faba bean, while cultural practices such as higher seeding rates and using competitive cultivars improve weed management (Lemerle et al., 2006). Intercropping can be used to produce peas in organic farming (Corre-Hellou et al., 2011). Crop rotations also prevent some weed species from becoming dominant in a field and also allow farmers to rotate herbicides. Weed control by hand may be also an option as part of an integrated weed control strategy, especially when the applied farming practices are incompatible with herbicide use (e.g. in organic cropping). However, in this case bigger inter-row distances have to be followed resulting in decreased yield due to lower total number of plants.

Optimum choice of herbicides depends on the spectrum of weed species (Fig. 4). Common weeds found in field pea crops in southern Europe are listed in Table 2. To our knowledge, in Canada, the leading producer of pea in the world, the herbicides imazamox, imazethapyr, saflufenacil, tepraloxydim, trifluralin, sethoxydim, s-metolachlor are available for use in pea. Currently, only a few herbicides are available for use in field pea crops Europe. The herbicides commonly used are pendimethalin, bentazon, imazamox, and quizalofop-p-ethyl.

Pendimethalin can be applied pre-plant to control many broadleaved and grass weeds and must be mechanically incorporated 5 to $10 \mathrm{~cm}$ deep. This herbicide when formulated as a microencapsulated (ME) aqueous capsule suspension could be applied pre-emergence of the crop. Moreover, the herbicide bentazon is approved for post-emergence use in pea to control broadleaf weeds at the two to fifth true leaf stage of the crop. Imazamox plus bentazon is also approved for postemergence use in pea to control both broadleaf and grass weeds. Quizalofop-p-ethyl is a selective, post-emergence herbicide for control of annual and perennial grass weeds.

Herbicide history must also be considered due to the risk of residues of herbicides for example used in previous cereal crops. Herbicide residues of sulfonylureas (i.e. chlorsulfuron, foramsulfuron, metsulfuron methyl, triasulfuron), triazines (i.e. terbuthylazine) and triketones (i.e. mesotrione, tembotrione, sulcotrione) can be very damaging to new pea crops.

\section{Broomrape (Orobanche) in pea}

Broomrapes (Phelipanche spp., Orobanche spp.) are obligate parasites that infect roots of dicotyledonous plants. Several broomrape species such as Orobanche crenata, O. foetida and Phelipanche aegyptiaca are reported to infect various legumes, while pea is infected only by $O$. crenata and not or hardly by $O$. foetida or $P$. aegyptiaca (Fernández-Aparicio and Rubiales, 2012). According to Fernández-Aparicio et al. (2010a) pea cultivation in the Mediterranean basin and Middle East is greatly influenced by Orobanche crenata, which is an annual plant that reproduces only by seeds; its underground part consists of the tubercle and pseudo roots, while above-ground it consists of a flowering stem 30-70 cm high, erect, nonbranching (Restuccia et al., 2009). Infection in pea is favoured by early sowing dates (October-December) and by mild winters and rainy autumns and springs (Rubiales et al., 2003).

Broomrape is difficult to control in pea (Rubiales et al., 2009b; Rubiales and Fernández-Aparicio, 2012). Imazethapyr applied pre- and post-emergence of the late crop sowings significantly reduced the infection and increased pea yield. Infection on pea and faba bean is reduced when these crops are intercropped with oat (Fernández-Aparicio et al., 2006). In another study, Fernández-Aparicio et al. (2010a) found that colonisation of field pea roots by arbuscular mycorrhizal fungi (Glomus mosseae and G. intraradices) reduces seed germination rate of broomrape species. The main reason for lower germination rates may be attributed to strigolactone production. Arbuscular mycorrhizal symbiosis decreases strigolactone production in pea. Strigolactones are signalling molecules that play a critical role for seed germination of broomrape and also for arbuscular mycorrhizal (AM) symbiosis (Garcia-Garrido et al., 2009). Thus, the positive effect of AM colonisation in reducing strigolactone production make AM fungi a promising tool for controlling pea infections by broomrape (Lopez-Raez et al., 2008).

Finally, the development of resistant pea varieties to broomrape is an efficient strategy to managing broomrape, 
330

although the breeding for broomrape resistance is difficult (Rubiales et al., 2009c). As a result of a breeding program, the first two pea resistant varieties to broomrape (cvs. Toro and Fandango) are now registered (Rubiales et al., 2015).

\section{Pest and disease management}

Bacterial and fungal diseases can cause severe damage to field pea crop. The most important diseases of field pea are ascochyta blight, powdery mildew, downy mildew and bacterial blight.

Ascochyta blight, caused by Ascochyta pisi, Mycosphaerella pinodes and Phoma pinodella, is one of the most important pea diseases worldwide (Bretag et al., 2006; Fernández-Aparicio et al., 2010b; Le May et al., 2009; Schoeny et al., 2010). Of these $M$. pinodes is the most harmful pathogen (McDonald and Peck, 2009; French, 2004; Lawyer, 1984). Specifically in the Mediterranean basin, it is considered as the second major constraint for the crop after broomrape (Rubiales et al., 2003) as can result in up to $75 \%$ yield loss (French, 2004). Ascochyta blight causes spot or lesions on leaves, stems and pods, and root rot (Richard et al., 2012). Current control methods include crop rotation, late sowing of crops, destruction of infected pea residues, use of pathogen-free seed, seed treatment and application of foliar fungicides (Bretag et al., 2006; Cesnulevičiene et al., 2014; Richard et al., 2012), while effort should be made to develop varieties resistant to ascochyta blight (Bretag et al., 2006). According to McDonald and Peck (2009) a decline of $15 \%$ per year in soil inoculum occurs, which means that a break of 6 years is required to reduce soil inoculum by 90\%. Hwang et al. (2006) also reported that ascochyta blight severity in pea crop was greater at higher seeding rates. For Mediterranean areas, McDonald and Peck (2009), as well as French (2004) suggested the delayed sowing as the best cultural strategy to reduce inoculation. In France and Spain, Schoeny $e t$ al. (2010) and Fernández-Aparicio et al. (2010b) also observed that disease severity reduced when pea was intercropped with cereals. Foliar sprays with fungicides (i.e. azoxystrobin) are also very effective against ascochyta blight, although their application may be prohibitive due to the low price of the final product.

Pea powdery mildew (Erysiphe pisi) and downy mildew (Peronospora viciae) are widely distributed all over the world. Powdery mildew is mostly damaging in late sowings or in late maturing varieties and can cause $25-50 \%$ yield losses, while management of pea powdery mildew relies on resistance cultivars, the use of fungicides and early planting (Fondevilla and Rubiales, 2012). Moreover, downy mildew fungus causes infection of seedlings, leaves and pods. Oospores carried with the seed and present in the soil play the main role in the disease (Stegmark, 1994). Foliar sprays or treatment of seeds with fungicides (i.e. metalaxyl) are very effective against downy mildew (Chang et al., 2013).

Bacterial blight (Pseudomonas syringae, either $p v$. pisi or $p v$. syringae) is a serious disease of field peas and can cause yield losses of 70\% (Fondevilla et al., 2012). It is primarily a seedborne pathogen, but infected pea residues can be an important source of inoculum. Control methods include crop rotation, use of pathogen-free seed, avoiding early planting and application of foliar bactericides (Hollaway et al., 2007). Rust (Uromyces spp.) is also an important disease of pea. Pea can be infected mainly by Uromyces pisi, followed by Uromyces viciaefabae, Uromyces striatus, Uromyces ciceris-arietini, Uromyces anthyllidis and Uromyces vignae (Barilli et al., 2012).

Other diseases that infect pea crops are rhizoctonia root rot, fusarium wilt and Aphanomyces root rot. Rhizoctonia root rot and fusarium wilt are caused by the soil-borne fungus Rhizoctonia solani and Fusarium solani f. sp. pisi, respectively, are common throughout the world. Also, Aphanomyces root rot (Aphanomyces euteiches Drechs.) is a destructive root disease of pea that can severely reduce seed yield (Conner $e$ t al., 2013; Pilet-Nayel et al., 2013). According to Wicker et al. (2001) Aphanomyces root rot is a serious disease of pea in France since 1993. In another study, Wicker and Rouxel (2001) reported that $A$. euteiches isolates from France was more aggressive than the isolates from other countries. Recently, eight germplasm lines of green pea with high level of resistance to Aphanomyces root rot were developed (McGee et al., 2012). These lines should be used in pea breeding programs to develop new varieties with resistance to $A$. euteiches. Crop rotations can minimize the risk of root diseases. A break of at least 2-3 years between field pea crops is recommended.

Field pea is also susceptible to virus and insects. Pea enation mosaic virus (PEMV) is an important virus disease. Tornos et al. (2008) reported that the infected plants exhibited symptoms such as yellow mosaic, curled leaves, vein enations and shortened internodes. The two main insects of field pea are pea leaf weevil and pea weevil. The pea leaf weevil (Sitona lineatus L.) is a significant pest of field pea and faba bean (Vicia faba L.) crops (Vankosky et al., 2009). Its adults feed on foliage but larvae prefer to feed on root nodules. Feeding damage resulting in reduced yield and nitrogen fixation (Vankosky $e t$ al., 2011). These researchers also reported that the thiamethoxam seed treatment reduced foliar feeding for 40 to $50 \mathrm{~d}$ after planting, while foliar insecticides have limited efficacy.

The pea weevil (Bruchus pisorum L.) is one of the most serious pests of pea causing severe damage to seeds (Clement $e t$ al., 2009). In a recent study, Seidenglanz et al. (2011) observed that the insecticides (lambda-cyhalothrin, alpha-cypermethrin, acetamiprid, thiacloprid) showed ovicidal and larvicidal effects, while lambda-cyhalothrin and alpha-cypermethrin were the most effective insecticides. Finally, other insects that infect pea crops are pea aphid (Acyrthosiphum pisum), black bean aphid (Aphis fabae), cutworms (Agrotis spp.), pea moth (Laspeyresia nigricana) and pea midge (Contarinia pisi).

\section{Irrigation}

Pea is well-adapted to the semi-arid conditions and can be grown without irrigation. The water requirement of field pea is similar to cereals. Wang et al. (2012) reported that dry pea had the highest water use efficiency (WUE) among the pulses (chickpea, lentil, faba bean, dry bean), while chickpea exhibited the lowest WUE.

High temperatures and water deficit during reproductive growth phase results in reduced seed number (Guilioni $e t$ al., 2003). Moreover, water deficit affects the distribution of pea roots. Benjamin and Nielsen (2006) observed that under irrigated conditions, about $80 \%$ of the field pea roots were in the top $23 \mathrm{~cm}$. Under dry conditions, about $66 \%$ of the field pea root mass was found up to a depth of $23 \mathrm{~cm}$. Water deficit 
affects also biological nitrogen fixation linked to asparaginerelated regulation of nitrogen fixation. A large amount of asparagine is found accumulating in nodules under drought conditions (Sulieman and Tran, 2013).

In southern Europe, an autumn planting provides an opportunity to limit the negative effects of water stress on grain pea yield as maximum root depth is reached earlier than in spring-sown crops (Vocanson et al., 2006b). The flowering and pod filling stages are the most critical stages for water need, especially the period between 10 days before flowering and 40 days after flowering (Sandaña and Calderini, 2012; Sorensen $e t$ al., 2003). The development of drought-tolerant pea varieties is also a strategy to improve yields in Mediterranean region. Grzesiak et al. (1999) reported differences in drought tolerance between varieties. According to Iglesias-García et al. (2015) the markers A6, AA175, AC74, AD57, AB141, AB64, Psblox2, PsAAP2_SNP4, and DipeptIV_SNP1 can be used in pea breeding programs for drought tolerance.

\section{Harvest and yield}

Vining peas are harvested with specialised pea vining machines when the pods are well filled but the seeds are still tender. Yield loss at harvest can be high and these are minimised by careful machine operation (Glancey et al., 1996). Dry grain peas are harvested with a conventional combine harvester. Timely harvesting of the crop is critical to avoid seed losses and harvesting in southern Europe starts when grain moisture content has fallen to $14 \%$ which is usually before the harvest of autumn-sown cereals. Losses at harvest can be high and wet weather is a significant risk. This is largely because, grown alone, peas are susceptible to lodging after flowering and lodging causes grain loss. Elkoca and Kantar (2006) reported that application of gibberellin inhibiter mepiquat chloride significantly shortened stem height and considerably improved lodging resistance. Spraying pea plants with $25 \mathrm{~g} \mathrm{ha}^{-1}$ mepiquat chloride (active ingredient) at early blooming stage was the most beneficial treatment (Elkoca and Kantar, 2006). However, mepiquat chloride is currently not approved for use in pea. Intercropping peas with oats reduces lodging. With intercropping, the optimal pea to oat ratio varying according to pea cultivar and local growth conditions (Kontturi et al., 2011).

Desiccation and crop-topping are well established techniques in pea crops. Desiccation of pea crops reduces the period from maturity to harvest while crop-topping is the late application of herbicides to kill surviving weeds before they set seed without affecting crop yield (Meldrum, 2011). Croptopping reduces harvest problems caused by late weed growth. The herbicides diquat and glyphosate are approved in some countries (i.e. Australia, Canada, USA), for use as a pre-harvest aid. To our knowledge, these herbicides are not approved for use on pea crop in southern European countries (i.e. Greece, Italy, Spain). The herbicide diquat is approved for use as desiccant in potato, alfalfa (i.e. Italy, Greece) and bean (i.e. Greece).

\section{Grain yield and crop development prospects}

Many researchers report yield instability in pea (Sagan et al., 1993; Cousin 1997), which is affected by many biotic and abiotic factors. The seed yield of dry peas range between 1.5 to $4 \mathrm{tha} \mathrm{a}^{-1}$. Nemecek et al. (2008) in a study of the introduction of grain legumes into European crop rotations reported lower production in Spain compared to Germany. The pea yielded $1.2 \mathrm{t} \mathrm{ha}{ }^{-1}$ in Spain with no addition of mineral fertilizers, whereas pea grown in Germany achieved a threefold yield of $3.3 \mathrm{t} \mathrm{ha} \mathrm{a}^{-1}$ with fertilizer input. However, in both cases, cereal crop (wheat) was twice as high yield as pea. This pattern is confirmed by FAO statistics reported by Stoddard (2013). It means that pea grain must have a substantially higher price

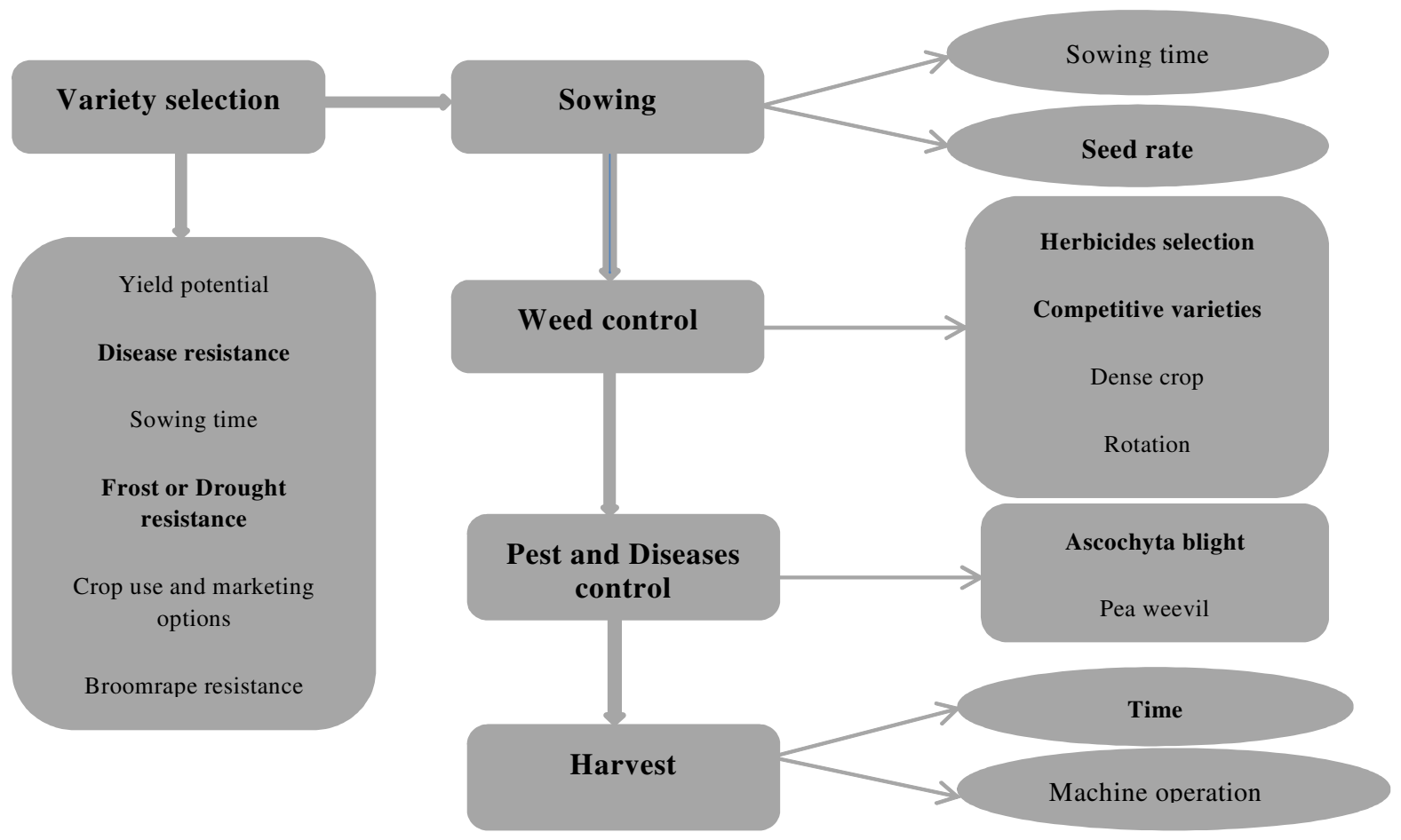

Fig. 5. The critical points in pea cultivation in Europe 
332

than cereal grains, considering even the longer-term rotational benefits of the inclusion of pea. In general, the yields in organic crops are typically lower than yields in conventional crops. Gopinath et al. (2009) reported this yield penalty to be 10$14 \%$. Pest, disease and weed infestation are less easy to control in organic farming systems than in those managed conventionally (Corre-Hellou and Crozat, 2005).

However, we can identify some pointers to development. While yields are lower than competing cereals, there are opportunities for relatively good performance compared with cereals. While average pea yields are less than half of wheat yields in Germany and the UK, they are more than half of wheat yields in many Mediterranean situations (Stoddard, 2013). This relatively good performance in southern Europe is attributable to the option to sown peas in autumn thus closing the yield gap attributable to the autumn sowing of cereals and spring sown of pea in northern Europe. This not only extends the growing season, but also helps pea escape drought. Therefore, in terms of the length of the growing season, pea is not disadvantaged against wheat in this region. We have also identified some pointers to crop improvement (Fig. 5). Improved cultivar resistance to ascochyta blight, greater winter hardiness, and better standing ability would all contribute to improving the performance of pea in southern Europe compared with cereals.

\section{Acknowledgment}

This work was supported by the European Commission within the FP7 research projects 'EUROLEGUME Enhancing of legumes growing in Europe through sustainable cropping for protein supply for food and feed (grant agreement no 613781)' and 'LEGUME FUTURES - Legume-supported cropping systems for Europe' (grant agreement no: 245216 CP-FP).

\section{References}

Annicchiarico P, Filippi L (2007). A field pea ideotype for organic systems of Northern Italy. Journal of Crop Improvement 20:193203.

Annicchiarico P, Iannucci A (2007). Winter survival of pea, faba bean and white lupin cultivars across contrasting Italian locations and sowing times, and implications for selection. Journal of Agricultural Science 145:611-622.

Ayaz S, McKenziem BA, Hill GD, McNeil DL (2004). Variability in yield of four grain legumes in a subhumid temperate environment. I. Yield and harvest index. Journal of Agricultural Science 142:9-19.

Barilli E, Moral A, Sillero JC, Rubiales D (2012). Clarification on rust species potentially infecting pea (Pisum sativum L.) crop and host range of Uromyces pisi (Pers.) Wint. Crop Protection 37:65-70.

Benjamin JG, Nielsen DC (2006). Water deficit effects on root distribution of soybean, field pea and chickpea. Field Crop Research 97:258-253.

Bilalis D, Karkanis A, Sidiras N, Travlos I, Efthimiadou A, Thomopoulos P, Kakabouki I (2012). Maize and legumes root growth and yield as influenced by organic fertilization, under Mediterranean environmental conditions. Romanian Agricultural Research 29:211-217.
Bourion V, Lejeune-Hénaut I, Munier-Jolain N, Salon C (2003). Cold acclimation of winter and spring peas: Carbon partitioning as affected by light intensity. European Journal of Agronomy 19:535548.

Brenes A, Trevino J, Centeno C, Yuste P (1989). Influence of peas (Pisum sativum) as a dietary ingredient and flavomycin supplementation on the performance and intestinal microflora of broiler chicks. British Poultry Science 30:81-89.

Bretag TW, Keane PJ, Price TV (2006). The epidemiology and control of ascochyta blight in field peas: a review. Australian Journal of Agricultural Research 57:883-902.

Brkic S, Milakovic Z, Kristek M, Antunovic M (2004). Pea yield and its quality depending on inoculation, nitrogen and molybdenum fertilization. Plant Soil and Environment 50:39-45.

Carr PM, Martin GB, Horsley RD (2009). Impact of tillage on field pea following spring wheat. Canadian Journal of Plant Science 89:281288.

Carranca C, De Varennes A, Rolston D (1999). Biological nitrogen fixation by fababean, pea and chickpea, under field conditions, estimated by the $15 \mathrm{~N}$ isotope dilution technique. European Journal of Agronomy 10(1):49-56.

Cazzato E, Laudadio V, Ceci E, Tufarelli V (2014). Effect of sulphur fertilization on fatty acid composition of faba bean (Vicia faba L.), white lupin (Lupinus albus L.) and pea (Pisum sativum L.) grains. Journal of Food, Agriculture and Environment 12(3-4):136-138

Chang KF, Hwang SF, Ahmed HU, Strelkov SE, Conner RL, Gossen BD, Bing DJ, Turnbull GD (2013). Yield loss and management of downy mildew on field pea in Alberta, Canada. Crop Protection 46:23-28.

Česnulevičiene R, Gaurilčikiene I, Ramanauskiene J (2014). Control of ascochyta blight (Ascochyta complex) in pea under Lithuanian conditions. Zemdirbyste-Agriculture 101:101-108.

Clayton G, Rice W, Blade S, Grant C, Harker N, Johnston A, Lafond G, Lupwayi N (1998). Minimizing Risk and Increasing Yield Stability in Field Pea Production. In: Proceedings from the $10^{\text {th }}$ Annual Meeting, Conference and Trade Show of the Saskatchewan Soil Conservation Association, February 11 \& 12, 1998, Regina, SK.

Clement SL, Mcphee KE, Elberson LR, Evans MA (2009). Pea weevil, Bruchus pisorum L. (Coleóptera: Bruchidae), resistance in Pisum sativum $\times$ Pisum fulvum interspecific crosses. Plant Breeding 128:478-485.

Conner RL, Chang KF, Hwang SF, Warkentin TD, McRae KB (2013). Assessment of tolerance for reducing yield losses in field pea caused by Aphanomyces root rot. Canadian Journal of Plant Science 93(3):473-482.

Corre-Hellou G, Crozat $\mathrm{Y}$ (2005). $\mathrm{N}_{2}$ fixation and $\mathrm{N}$ supply in organic pea (Pisum sativum L.) cropping systems as affected by weeds and peaweevil (Sitona lineatus L.). European Journal of Agronomy 22:449-458.

Corre-Hellou G, Dibet A, Hauggaard-Nielsen H, Crozat Y, Gooding M, Ambus P, ... Jensen ES (2011). The competitive ability of peabarley intercrops against weeds and the interactions with crop 
productivity and soil N availability. Field Crops Research 122:264 272.

Cousin R (1997). Peas (Pisum sativum L.). Field Crops Research 53(13):111-130.

Dahl WJ, Foster LM, Tyler RT (2012). Review of the health benefits of peas (Pisum sativum L.). British Journal of Nutrition 108:S3-S10.

Deibert EJ, Utter RA (2004). Field pea growth and nutrient uptake: Response to tillage systems and nitrogen fertilizer applications. Communications in Soil Science and Plant Analysis 35:1141-1165.

Duzdemir O, Kurunc A, Unlukara A (2009). Response of pea (Pisum sativum) to salinity and irrigation water regime. Bulgarian Journal of Agricultural Science 15:400-409.

Efthimiadou A, Karkanis A, Bilalis D, Efthimiadis P (2009). The phenomenon of crop-weed competition; a problem or a key for sustainable weed management? Journal of Food Agriculture and Environment 7:861-868.

Elkoca E, Kantar F (2006). Response of pea (Pisum sativum L.) to mepiquat chloride under varying application doses and stages. Journal of Agronomy and Crop Science 192:102-110.

FAOSTAT (2015). Food and Agriculture Organization of the United Nations Statistics. http://faostat.fao.org/.

Fernandez AL, Sheaffer CC, Wyse DL, Michaels TE (2012). Yield and weed abundance in early- and late-sown field pea and lentil. Agronomy Journal 104:1056-1064.

Fernández-Aparicio M, Garcia-Garrido JM, Ocampo JA, Rubiales D (2010a). Colonisation of field pea roots by arbuscular mycorrhizal fungi reduces Orobanche and Phelipanche species seed germination. Weed Research 50:262-268.

Fernández-Aparicio M, Amri M, Kharrat M, Rubiales D (2010b). Intercropping reduces Mycosphaerella pinodes severity and delays upward progress on the pea plant. Crop Protection 29(7):744-750.

Fernández-Aparicio M, Rubiales D (2012). Differential response of pea (Pisum sativum) to Orobanche crenata, Orobanche foetica and Phelipanche aegyptiaca. Crop Protection 31:27-30.

Fernández-Aparicio M, Sillero JC, Rubiales D (2006). Intercropping with cereals reduces infection by Orobanche crenata in legumes. Crop Protection 26:1166-1172.

Fondevilla S, Martín-Sanz A, Satovic Z, Fernández-Romero MD, Rubiales D, Caminero C (2012). Identification of quantitative trait loci involved in resistance to Pseudomonas syringae pv. syringae in pea (Pisum sativum L.). Euphytica 186:805-812.

Fondevilla S, Rubiales D (2012). Powdery mildew control in pea. A review. Agronomy for Sustainable Development 32:401-409.

French RJ (2004). PEA/Agronomy. In: Wrigley C, Corke H, Walker $\mathrm{C}$ (Eds). Encyclopaedia of grain science. Elsevier Academic Press pp 427-437.

Gan YT, Miller PR, McConkey BG, Zentner RP, Liu PH, McDonald CL (2003). Optimum plant population density for chickpea and dry pea in a semiarid environment. Canadian Journal of Plant Science 83(1):1-9.

Gallejones P, Castellón A, del Prado A, Unamunzaga O, Aizpurua A (2012). Nitrogen and sulphur fertilization effect on leaching losses, nutrient balance and plant quality in a wheat-rapeseed rotation under a humid Mediterranean climate. Nutrient Cycling in Agroecosystems 93(3):337-355.

Garcia-Garrido JM, Lendzemo V, Castallanos-Morales V, Steinkellner S, Vierheiling H (2009). Strigolactones, signals for parasitic plants and arbuscular mycorrhizal fungi. Myccorhiza 19:449-459.

Gatel F, Grosjean F (1990). Composition and nutritive value of peas for pigs: A review of European results. Livestock Production Science 26(3):155-175.

Ghaley BB, Hauggaard-Nielsen H, Høgh-Jensen H, Jensen ES (2005). Intercropping of wheat and pea as influenced by nitrogen fertilization. Nutrient Cycling in Agroecosystems 73:201-212.

Glancey JL, Kee WE, Wootten TL, Dukes MD, Postles BC (1996). Field losses for mechanically harvested green peas. Journal of Vegetable Crop Production 2:61-81.

Gopinath KA, Saha S, Mina BL, Pande H, Kumar N, Srivastva AK, Gupta HS (2009). Yield potential of garden pea (Pisum sativum L.) varieties, and soil properties under organic and integrated management systems. Archives of Agronomy and Soil Science 55:157-167.

Grzesiak S, Grzesiak M, Hura T (1999). Effect of soil drought during the vegetative phase of seedling growth on the uptake of $14 \mathrm{CO}_{2}$ and the accumulation ad translocation of $14 \mathrm{C}$ in cultivars of field bean (Vicia faba L. var. minor) and dried pea (Pisum sativum L.) of different drought tolerance. Journal of Agronomy and Crop Science 183:183-192.

Gueguen J, Barbot J (1988). Quantitative and qualitative variability of pea (Pisum sativum L.) protein composition. Journal of the Science of Food and Agriculture 42:209-224.

Guilioni L, Wéry J, Lecoeur J (2003). High temperature and water deficit may reduce seed number in field pea purely by decreasing plant growth rate. Functional Plant Biology 30(11):1151-1164.

Ha KV, Marschner P, Bünemann EK, Smernik RJ (2007). Chemical changes and phosphorus release during decomposition of pea residues in soil. Soil Biology and Biochemisty 39:2696-2699.

Harker KN, Blackshaw RE, Clayton GW (2001). Timing weed removal in field pea (Pisum sativum). Weed Technology 15:277283.

Harker KN, Clayton GW, Blackshaw RE (2008). Comparison of leafy and semileafless pea for integrated weed management. Weed Technology 22:124-131.

Hebblethwaite PD, McGowan M (1980). The effects of soil compaction on the emergence, growth and yield of sugar beet and peas. Journal of the Science of Food and Agriculture 31:1131-1141.

Hollaway GJ, Bretag TW, Price TV (2007). The epidemiology and management of bacterial blight (Pseudomonas syringae pv. pisi) of field pea (Pisum sativum) in Australia: Review. Australian Journal of Agricultural Research 58:1086-1099.

Hwang SF, Conner RL, Chang KF, Gossen BD, Su H, Howard RJ, Turnbull GD (2006). Impact of seeding rate and depth on mycosphaerella blight and seed yield of field pea. Canadian Journal of Plant Science 86(3):845-853.

Iglesias-García R, Prats E, Fondevilla S, Satovic Z, Rubiales D (2015). 
334

Quantitative Trait Loci associated to drought adaptation in pea (Pisum sativum L.). Plant Molecular Biology Reporter 33:17681778.

Johnston AM, Stevenson FC (2001). Field pea response to seeding depth and P fertilization. Canadian Journal of Plant Science 81(3):573-575.

Kaiser BN, Gridley KL, Brady JN, Phillips T, Tyerman SD (2005). The role of molybdenum in agricultural plant production. Annals of Botany 96(5):745-754.

Khan HR, Paull JG, Siddique KHM, Stoddard FL (2010). Faba bean breeding for drought-affected environments: A physiological and agronomic perspective. Field Crops Research 115(3):279-286.

Knight JD (2012). Frequency of field pea in rotations impacts biological nitrogen fixation. Canadian Journal of Plant Science 82:10051011.

Kontturi M, Laine A, Niskanen M, Hurme T, Hyövelä M, PeltonenSainio P (2011). Pea-oat intercrops to sustain lodging resistance and yield formation in northern European conditions. Acta Agriculturae Scandinavica, Section B-Soil Plant Science 61:612621.

Lafond J, Pageau D (2010). Phosphorus and potassium fertilization of dry pea. Canadian Journal of Plant Science 90(5):629-636.

Lanza M, Bella M, Priolo A, Fasone V (2003). Peas (Pisum sativum L.) as an alternative protein source in lamb diets: Growth performances, and carcass and meat quality. Small Ruminant Research 47(1):6368.

Lawyer AS (1984). Foliar diseases caused by fungi: diseases caused by Ascochyta spp. In: Compendium of pea diseases. Hagedorn DJ (Ed). APS Press, The American Phytopathological Society: St. Paul, MNpp 11-15.

Le May C, Jumel S, Schoeny A, Tivoi B (2009). Ascochyta blight development on a new winter pea genotype highly reactive to photoperiod under field conditions. Field Crop Research 111:3238.

Legrand S, Marque G, Blassiau C, Bluteau A, Canoy AS, Fontaine V, Jaminon O, Bahrman N, Mautord J, Morin J, Petit A, Baranger A, Rivière N, Wilmer J, Delbreil B, Lejeune-Hénaut I (2013). Combining gene expression and genetic analyses to identify candidate genes involved in cold responses in pea. Journal of Plant Physiology 170:1148-1157.

Lemerle D, Verbeek B, Diffey S (2006). Influences of field pea (Pisum sativum) density on grain yield and competitiveness with annual ryegrass (Lolium rigidum) in south-eastern Australia Australian Journal of Experimental Agriculture 46:1465-1472.

Leonforte A, Forster JW, Redden RJ, Nicolas ME, Salisbury PA (2013). Sources of high tolerance to salinity in pea (Pisum sativum L.). Euphytica 189:203-216.

Lithourgidis AS, Vlachostergios DN, Dordas CA, Damalas CA (2011). Dry matter yield, nitrogen content, and competition in pea-cereal intercropping system. European Journal of Agronomy 34(4):287294.

Lopez-Raez JA, Matusova R, Cardoso C, Jamil M, Charnikhova T, Kohlen W, Ruyter-Spira C, Verstappena F, Bouwmeestera H
(2008). Strigolactones: ecological significance and use as a target for parasitic plant control. Pest Management Science 64:471-477.

Lupwayi NZ, Lafond GP, May WE, Holzapfel CB, Lemke RL (2012). Intensification of field pea production: impact on soil microbiology. Agronomy Journal 104:1189-1196.

MacWilliam S, Wismer M, Kulshreshtha S (2014). Life cycle and economic assessment of Western Canadian pulse systems: The inclusion of pulses in crop rotations. Agricultural Systems 123:4353.

Maqbool A, Shafiq S, Lake L (2010). Radiant frost tolerance in pulse crops - A review. Euphytica 170:1-12.

McDonald GK, Peck D (2009). Effects of crop rotation, residue retention and sowing time on the incidence and survival of ascochyta blight and its effect on grain yield of field peas (Pisum sativum L.). Field Crops Research 111:11-21.

McGee RJ, Coyne CJ, Pilet-Nayel ML, Moussart A, Tivoli B, Baranger A, Hamon C, Vandemark G, McPhee K (2012). Registration of pea germplasm lines partially resistant to aphanomyces root rot for breeding fresh or freezer pea and dry pea types. Journal Plant Registrations 6(2):203-207.

McKenzie RH, Middleton AB, Solberg ED, DeMulder J, Flore N, Clayton GW, Bremer E (2001). Response of pea to rhizobia inoculation and starter nitrogen in Alberta. Canadian Journal of Plant Science 81:637-643.

Meldrum A (2011). Desiccation and Croptopping in pulses. Australian Pulse Bulletin 17:1-4.

Meyer DW, Badaruddin M (2001). Frost tolerance of ten seedling legume species at four growth stages. Crop Science 41 (6):18381842.

Nemecek T, Richthofen JS, Dubois G, Casta P, Charles R, Pahl H (2008). Environmental impacts of introducing grain legumes into European crop rotations. European Journal of Agronomy 28:380393.

Nikolopoulou D, Grigorakis K, Stasini M, Alexis MN, Iliadis K (2007). Differences in chemical composition of field pea (Pisum sativum) cultivars: Effects of cultivation area and year. Food Chemistry 103:847-852.

Pacyna S, Schulz M, Scherer HW (2006). Influence of sulphur supply on glucose and ATP concentrations of inoculated broad beans (Vicia faba minor L.): Dedicated to Prof. Dr. Dr. h.c. W. Werner on the occasion of his 75 th birthday. Biology and Fertility of Soils 42(4):324-329.

Pilet-Nayel ML, Muehlbauer FJ, McGee RJ, Kraft JM, Baranger A, Coyne CJ (2013). Consistent quantitative trait loci in pea for partial resistance to Aphanomyces euteiches isolates from the United States and France. Phytopathology 95(11):1287-1293.

Piotrowska A, Wilczewski E (2012). Effects of catch crops cultivated for green manure and mineral nitrogen fertilization on soil enzyme activities and chemical. Geoderma 189-190:72-80.

Poudel DD, Horwath WR, Mitchell JP, Temple SR (2001). Impacts of cropping systems on soil nitrogen storage and loss. Agricultural Systems 68(3):253-268.

Pristeri A, Preiti G, Gresta F, Gelsomino A, Monti M (2012). 
Intercropping grain legume/cereal for ecologically intensifying the winter cereal cropping system. In: Proceeding of XII European Society of Agronomy Congress 20-24 August 2012 Helsinki, Finland pp 504-505.

Raveneau MP, Coste F, Moreau-Valancogne P, Lejeune-Hénaut I, Durr C (2011). Pea and bean germination and seedling responses to temperature and water potential. Seed Science Research 21(3):205213.

Restuccia A, Marchese M, Mauromicale G, Restuccia G (2009). Biological characteristics and control of Orobanche crenata Forsk., A review. Italian Journal of Agronomy 1:53-68.

Richard B, Jumel S, Rouault F, Tivoli B (2012). Influence of plant stage and organ age on the receptivity of Pisum sativum to Mycosphaerella pinodes. European Journal of Plant Pathology 132:367-379.

Rubiales D, Pérez-de-Luque A, Cubero JI, Sillero JC (2003). Crenate broomrape (Orobanche crenata) infection if field pea cultivars. Crop Protection 22:865-872.

Rubiales D, Fernández-Aparicio M, Moral A, Barilli E, Sillero JC, Fondevilla S (2009a). Disease resistance in pea (Pisum sativum L.) types for autumn sowings in Mediterranean environments. Czech Journal of Genetics and Plant Breeding 4:135-142.

Rubiales D, Fernández-Aparicio M, Wegmann K, Joel DM (2009b). Revisiting strategies for reducing the seedbank of Orobanche and Phelipanche spp. Weed Research 49 (Suppl. 1):23-33.

Rubiales D, Fernández-Aparicio M, Pérez-de-Luque A, Castillejo MA, Prats E, Sillero JC, Rispail N, Fondevilla S (2009c). Breeding approaches for crenate broomrape (Orobanche crenata Forsk.) management in pea (Pisum sativum L.). Pest Management Science 65:553-559.

Rubiales D, Fernández-Aparicio M (2012). Innovations in parasitic weeds management in legume crops. A review. Agronomy for Sustainable Development 32:433-449.

Rubiales D, Barilli E, Bani M, Rispail N, Aznar-Fernández T, Fondeevilla $S$ (2015). Use of wild relatives in pea breeding for disease resistance. Legumes Perspectives 7:21-22.

Sagan M, Ney B, Duc G (1993). Plant symbiotic mutants as a tool to analyse nitrogen nutrition and yield relationship in field-grown peas (Pisum sativum L.). Plant and Soil 153:33-45.

Sandaña P, Calderini DF (2012). Comparative assessment of the critical period for grain yield determination of narrow-leafed lupin and pea. European Journal of Agronomy 40:94-101.

Sandaña P, Pinochet D (2014). Grain yield and phosphorus use efficiency of wheat and pea in a high yielding environment. Journal of Soil Science and Plant Nutrition 14(4):973-986.

Schneider AVC (2002). Overview of the market and consumption of pulses in Europe. The British Journal of Nutrition 88:S243-50.

Schoeny A, Jumel S, Roualt F, Lemarchand E, Tivoli B (2010). Effect and underlying mechanisms of pea-cereal intercropping on the epidemic development of ascochyta blight. European Journal of Plant Pathology 126:317-331.

Scherer HW, Lange A (1996). N2 fixation and growth of legumes as affected by sulphur fertilization. Biology and Fertility of Soils 23 (4):449-453.
Seidenglanz M, Rotrekl J, Poslušná J, Kolaík P (2011). Ovicidal effects of thiacloprid, acetamiprid, lambda-cyhalothrin and alphacypermethrin on Bruchus pisorum L. (Coleoptera: Chrysomelidae) eggs. Plant Protection Science 47:109-114.

Shafiq S, Mather DE, Ahmad M, Paull JG (2012). Variation in tolerance to radiant frost at reproductive stages in field pea germplasm. Euphytica 186:831-845.

Siczek A, Lipiec J, Wielbo J, Szarlip P, Kidaj D (2013). Pea growth and symbiotic activity response to Nod factors (lipochitooligosaccharides) and soil compaction. Applied Soil Ecology 72:181-186.

Sorensen JN, Edelenbos M, Wienbeg L (2003). Drought effects on green pea texture and related physical-chemical properties at comparable maturity. Journal of the American Society for Horticultural Science 128:128-135.

Spies JM, Warkentin T, Shirtliffe S (2010). Basal branching in field pea cultivars and yield-density relationships. Canadian Journal of Plant Science 90(5):679-690.

Spies JM, Warkentin TD, Shirtliffe SJ (2011). Variation in field pea (Pisum sativum) cultivars for basal branching and weed competition. Weed Science 59:218-223.

Stegmark R (1994). Downy mildew on peas (Perosnospora viciae f. sp. pisi). Agronomie 14:641-647.

Stoddard FL (2013). The case studies of participant expertise in Legume Futures. Legume Futures Report 1.2. Retrieved 12 Mar 2016 from www.legumefutures.de.

Sulieman S, Tran LS (2013). Asparagines: an amide of particular distinction in the regulation of symbiotic nitrogen fixation of legumes. Critical Reviews in Biotechnology 33:309-327.

Światecka D, Światecki A, Kostyra H, Marciniak-Darmochwa FK, Kostyra E (2010). The impact of pea protein hydrolysates on bacterial physiological activity - An in vitro study. International Journal of Food Microbiology 140(2-3):263-270.

Tawaha AM, Turk MA (2004). Field pea seeding management for semi-arid Mediterranean conditions. Journal of Agronomy and Crop Science 190:86-92.

Tornos T, Cebrián MC, Córdoba-Sellés MC, Alfaro-Fernández A, Herrera-Vásquez JA, Font MI, Jorda MC (2008). First report of Pea enation mosaic virus infecting pea and broad bean in Spain. Plant Disease 92:1469-1469.

Vankosky M, Dosdall LM, Carcamo HA (2009). Distribution, biology and integrated management of the pea leaf weevil, Sitona lineatus L. (Coleoptera: Curculionidae), with an analysis of research needs. CAB Reviews: Perspectives in Agriculture, Veterinary Science, Nutrition and Natural Resources 4:1-18.

Vankosky MA, Cárcamo HA, McKenzie RH, Dosdall LM (2011). Integrated management of Sitona lineatus with nitrogen fertilizer, Rhizobium, and thiamethoxam insecticide. Agronomy Journal 103:565-572.

Vocanson A, Jeuffroy MH (2008). Agronomic performance of different pea cultivars under various sowing periods and contrasting soil structures. Agronomy Journal 100(3):748-759.

Vocanson A, Roger-Estrade J, Boizard H, Jeuffroy MH (2006a). Effects 
336

of soil structure on pea (Pisum sativum L.) root development according to sowing date and cultivar. Plant and Soil 281(1-2):121135.

Vocanson A, Jeuffroy MH, Roger-Estrade J (2006b). Effect of sowing date and cultivar on root system development in pea (Pisum sativum L.). Plant and Soil 283(1-2):339-352.

Wang X, Gan Y, Hamel C, Lemke R, McDonald C (2012). Water use profiles across the rooting zones of various pulse crops. Field Crop Research 134:130-137.

Wicker E, Hullé M, Rouxel F (2001). Pathogenic characteristics of isolates of Aphanomyces euteiches from pea in France. Plant Pathology 50(4):433-442.

Wicker E, Rouxel F (2001). Specific behaviour of French Aphanomyces euteiches Drechs. populations for virulence and aggressiveness on pea, related to isolates from Europe, America and New Zealand. European Journal of Plant Pathology 107(9):919-929.
Zhao FJ, Wood AP, McGrath SP (1999). Effects of sulphur nutrition on growth and nitrogen fixation of pea (Pisum sativum L.). Plant and Soil 212(2):209-219.

Zohary D, Hopf M (1973). Domestication of pulses in the old world. Science 182(4115):887-894.

Zong X-x, Ford R, Redden RR, Guan, J-p, Wang S-m (2009). Identification and analysis of genetic diversity structure within Pisum genus based on microsatellite markers. Agricultural Sciences in China 8:257-267. 